\title{
PENGARUH PEMBERIAN PROBIOTIK KOMERSIAL PADA PAKAN TERHADAP LAJU PERTUMBUHAN DAN EFISIENSI PAKAN UDANG VANAME (Litopenaeus vannamei)
}

\section{The Present Effect of Probiotics Commercial on Feed Towards Growth and Feed Efficiency of Vaname Shrimp (Litopenaeus Vannamei)}

\author{
Syaiful Anwar ${ }^{1}$, Muhammad Arief ${ }^{2}$ dan Agustono $^{2}$ \\ ${ }^{1}$ Program Studi Budidaya Perairan, Fakultas Perikanan dan Kelautan, Universitas Airlangga, Surabaya \\ ${ }^{2}$ Departemen Manajemen Kesehatan Ikan dan Budidaya Perairan, Fakultas Perikanan dan Kelautan, Universitas \\ Airlangga, Surabaya \\ *syaiful-an-11@fpk.unair.ac.id
}

\begin{abstract}
Abstrak
Udang vaname (Litopenaeus vannamei) merupakan suatu komoditas yang memiliki nilai ekonomis penting di Indonesia. Dari tahun ke tahun permintaan udang vaname akan terus meningkat. Salah satu cara untuk memenuhi kebutuhan permintaan udang vaname adalah peningkatan produksi dengan mempercepat pertumbuhan ikan. Tujuan dari penelitian ini adalah untuk mengetahui pengaruh pemberian probiotik komersial pada pakan terhadap pertumbuhan dan efisiensi pakan udang vaname.

Penelitian ini menggunakan metode eksperimental, yakni dengan Rancangan Acak Lengkap (RAL). Udang vaname dipelihara selama 35 hari dengan sepuluh perlakuan dan tiga ulangan. Data yang diperoleh diolah menggunakan Analysis of Variance (ANOVA) dan dilanjutkan Uji Berjarak Duncan bila didapatkan hasil yang berbeda nyata.

Hasil dari penelitian menunjukkan bahwa pemberian probiotik pada pakan menghasilkan laju pertumbuhan dan efisiensi pakan yang berbeda nyata $(\mathrm{p}<0,05)$. Pertumbuhan udang vaname (Litopenaeus Vannamei) yang terbaik terdapat pada perlakuan P9 sebesar 1,41 $\pm 0,08$. Efisiensi pakan tertinggi terdapat pada perlakuan P9 sebesar 48,80 $\pm 1,23$.
\end{abstract}

Kata kunci : Probiotik, Pertumbuhan, Efisiensi Pakan, Litopenaeus vannamei

\begin{abstract}
White shrimp (Litopenaeus vannamei) is one commodity that has an important economic value in Indonesia. From year to year white shrimp demand will continue to increase. One way to fullfil the necessity of white vaname demand is increasing production by accelerating the growth of fish. The aim of this research was to determine the effect of commercial probiotic on feed towards growth and feed efficiency white shrimp.

This research used experimental method, using a Completely Randomized Design (CRD). White shrimp maintained for 35 days with ten treatments and three replications. The obtained data were processed using Analysis of Variance (ANOVA) and followed by Duncan Multiple Range Test if there was significant data.

Results of the research showed that the probiotics in feed resulted in growth rate and feed efficiency were significantly different $(\mathrm{p}<0.05)$. Growth white shrimp (Litopenaeus vannamei) the best there is at $\mathrm{P} 9$ treatment of $1.41 \pm 0.08$. Feed efficiency is highest on P9 treatment of $48.80 \pm 1.23$.
\end{abstract}

Key words: Probiotics, Growth, Feed Efficiency, White Shrimp

\section{PENDAHULUAN}

Udang vaname (Litopenaeus vannamei) merupakan suatu komoditas perikanan yang memiliki nilai ekonomis penting di Indonesia. Produksi udang vaname dari tahun 2010 hingga 2013 mengalami kenaikan sebanyak $19,46 \%$ dan diharapkan tahun 2014 produksi udang vaname dapat melampau target lebih dari
100\%. Diprediksikan permintaan udang vaname dari tahun ke tahun akan terus meningkat (Kementrian Kelautan dan Perikanan, 2013). Pemenuhan akan permintaan dapat diatasi dengan mempercepat pertumbuhan. Salah satu cara yang dapat mempercepat pertumbuhan adalah dengan cara pemberian pakan yang tepat (Hadadi dkk, 2007). 
Pakan adalah salah satu unsur penting dalam budidaya yang menunjang pertumbuhan dan kelangsungan hidup ikan budidaya. Pakan pada kegiatan budidaya umumnya merupakan pakan komersial yang menghabiskan sekitar $60-70 \%$ dari total biaya produksi yang dikeluarkan. Penggunaan pakan yang tepat dan kualitas pakan yang baik akan meningkatkan produksi udang dan secara langsung akan meningkatkan keuntungan (Sumeru dan Anna, 1992). Hal inilah yang menyebabkan pentingnya pakan sehingga perlu dilakukan kegiatan penelitian untuk memperbaiki nilai nutrisi pakan yaitu dengan penambahan probiotik.

Probiotik adalah produk yang tersusun oleh biakan mikroba yang bersifat menguntungkan dan memberikan dampak bagi peningkatan keseimbangan mikroba saluran usus hewan inang (Fuller, 1987). Penggunaan probiotik ada dua macam yaitu: pertama melalui lingkungan (air dan dasar tambak) dan yang kedua melalui oral (dicampurkan ke dalam pakan). Aplikasi cara kedua dapat meningkatkan kualitas pakan dengan menambahkan bahan aditif dalam bentuk probiotik yang berisi mikroba pengurai ke dalam pakan dan juga berfungsi untuk memperbaiki kualitas pakan dengan cara melalui proses penguraian sehingga dapat meningkatkan nilai nutrisi pakan (Mansyur dan Malik, 2008).

Hal ini sesuai dengan pernyataan Soccol et al. (1993) bahwa probiotik bermanfaat dalam mengatur lingkungan mikroba yang ada pada usus, menghalangi mikroorganisme patogen usus dan memperbaiki efisiensi pakan dengan melepas enzim yang dapat membantu proses pencernaan makanan. Penelitian ini dilakukan untuk mengetahui pengaruh pemberian probiotik komersial pada pakan terhadap laju pertumbuhan dan efisiensi pakan pada udang vaname.

\section{METODOLOGI}

Waktu dan Tempat

Penelitian ini akan dilaksanakan di
Laboratorium Pendidikan Fakultas Perikanan dan Kelautan Universitas Airlangga. Analisis proksimat pakan dilakukan di Laboratorium Pakan Fakultas Kedokteran Hewan Universitas Airlangga. Penelitian ini akan dilaksanakan pada Juni hingga Juli 2015.

\section{Materi Penelitian}

Peralatan Penelitian

Materi penelitian yang digunakan terdiri dari alat dan bahan penelitian. Alat penelitian yang digunakan sebagai sarana dan prasarana pemeliharaan udang antara lain antara lain adalah 30 buah akuarium dengan ukuran $50 \times 30 \times 35 \mathrm{~cm}^{3}$, selang aerasi dan 30 buah batu aerasi, aerator, tiga bak tandon, timbangan analitik, penggaris, trash bag, mesh net, wadah pakan, baskom, termometer, $\mathrm{pH}$ pen, ammonia test kit, refraktometer dan DO test kit.

Bahan Penelitian

Bahan penelitian yang digunakan dalam penelitian ini adalah udang vaname dari Gresik dengan panjang tubuh sekitar 5-7 cm dan berat sekitar 2-4 gram, pakan pelet. Probiotik yang digunakan dalam penelitian ini merupakan tiga probiotik komersial. Probiotik A terdiri dari beberapa bakteri yaitu Lactobacillus plantarum, Bacillus sp., Bacillus subtilis serta Nitrosomonas europea; Probiotik B Lactobacillus plantarum, Bacillus suptilis, dan Bacillus licheniformis, serta Probiotik C Nitrosomonas sp., Nitrobacter sp., Lactobacillus sp. dan Geobacillus sp.

\section{Metode Penelitian}

Rancangan yang digunakan adalah Rancangan Acak Lengkap (RAL) dengan jumlah perlakuan sebanyak sepuluh, dan jumlah ulangan sebanyak tiga kali (Kusriningrum, 2008).

Perlakuan yang digunakan pada penelitian ini yaitu:

$\mathrm{P}_{0}$ : pakan tanpa probiotik (Kontrol)

$\mathrm{P}_{1}$ : pakan dengan probiotik A5 $\mathrm{ml} / \mathrm{kg}$

$\mathrm{P}_{2}$ : pakan dengan probiotik $\mathrm{A} 10 \mathrm{ml} / \mathrm{kg}$

$\mathrm{P}_{3}$ : pakan dengan probiotik $\mathrm{A} 15 \mathrm{ml} / \mathrm{kg}$ 
$\mathrm{P}_{4}$ : pakan dengan probiotik $\mathrm{B} 5 \mathrm{ml} / \mathrm{kg}$

$\mathrm{P}_{5}$ : pakan dengan probiotik $\mathrm{B} 10 \mathrm{ml} / \mathrm{kg}$

$\mathrm{P}_{6}$ : pakan dengan probiotik $\mathrm{B} 15 \mathrm{ml} / \mathrm{kg}$

$\mathrm{P} 7$ : pakan dengan probiotik C $5 \mathrm{ml} / \mathrm{kg}$

$\mathrm{P} 8$ : pakan dengan probiotik $\mathrm{C} 10 \mathrm{ml} / \mathrm{kg}$

$\mathrm{P} 9$ : pakan dengan probiotik $\mathrm{C} 15 \mathrm{ml} / \mathrm{kg}$

\section{Prosedur Kerja}

Akuarium dibersihkan dan disterilisasi terlebih dahulu dengan klorin 1 ppm agar terhindar dari bakteri dan penyakit, selanjutnya akuarium dibilas dan dikeringkan. Akuarium dibersihkan menggunakan deterjen dan diberi klorin 1 ppm sebagai desinfektan (Haliman dan Adijaya, 2006). Media pemeliharaan adalah air payau dengan salinitas 15 ppt sebanyak 40 L tiap akuarium, masing-masing akuarium diberi satu batu aerasi dan diaerasi selama 15 hari (Widanarni dkk., 2012). Tiap akuarium ditebar udang dengan kepadatan 15 ekor per 40 liter air payau dan setara sekitar 300 ekor per $\mathrm{m}^{3}$.

Pakan yang akan digunakan pada penelitian dianalisis proksimat terlebih dahulu untuk mengetahui kandungan nutrisi dari pakan tersebut. Pemberian pakan pelet komersial secara ad libitum, tiap akuarium berisi 15 ekor udang (Rodryguez et al., 2003). Frekuensi pemberian pakan pada udang vaname berumur 31-40 hari adalah lima kali sehari (Widagdo, 2011) pada pukul 07.00, 11.00, 15.00, 19.00 dan 23.00 WIB (Sukenda dkk., 2006). Pemberian probiotik pada pakan dilakukan setiap 30 menit sebelum waktu makan udang. Probiotik yang digunakan setiap dosis ditambah dengan larutan Phospat Buffered Saline (PBS) sebanyak $100 \mathrm{ml}$ kemudian disemprotkan secara merata. Menurut Fitriani (2013) pakan yang diberikan probiotik dicampur merata kemudian dikeringkan selama 30 menit.

Menurut Widagdo (2011), sampling pertumbuhan dilakukan setiap 7 hari sekali. Pengukuran kualitas air dilakukan setiap 7 hari sekali pada pemeliharaan udang vaname. Adapun parameter kualitas air yang diukur antara lain suhu, $\mathrm{pH}$, ammonia dan DO.

\section{HASIL DAN PEMBAHASAN Hasil}

Hasil pengamatan laju pertumbuhan harian pada udang vaname selama 35 hari dapat dilihat pada Tabel 5.1.

Uji statistik laju pertumbuhan harian menunjukkan bahwa pemberian pakan dengan probiotik yang berbeda menghasilkan laju pertumbuhan harian udang vaname yang berbedanyata $(\mathrm{p}<0,05)$. Setelah dilanjutkan dengan uji Jarak Berganda Duncan (Duncan's Multiple Range Test) dapat diketahui bahwa laju pertumbuhan harian tertinggi terdapat pada perlakuan $\mathrm{P9}$ yang berbeda nyata dengan perlakuan $\mathrm{P} 0$, sedangkan laju pertumbuhan harian terendah didapat pada perlakuan P7.

Tabel 5.1 Laju Pertumbuhan Harian Ratarata udang vaname pada Setiap Perlakuan

\begin{tabular}{cc}
\hline Perlakuan & $\begin{array}{c}\text { Laju Pertumbuhan } \\
\text { Harian } \pm \text { SD }\end{array}$ \\
\hline P0 & $1,16^{\mathrm{b}} \pm 0,15$ \\
P1 & $1,38^{\mathrm{a}} \pm 0,14$ \\
P2 & $1,15^{\mathrm{a}} \pm 0,05$ \\
P3 & $1,26^{\mathrm{ab}} \pm 0,17$ \\
P4 & $1,15^{\mathrm{b}} \pm 0,06$ \\
P5 & $1,28^{\mathrm{ab}} \pm 0,10$ \\
P6 & $1,24^{\mathrm{ab}} \pm 0,12$ \\
P7 & $1,04^{\mathrm{b}} \pm 0,11$ \\
P8 & $1,27^{\mathrm{ab}} \pm 0,05$ \\
P9 & $1,41^{\mathrm{a}} \pm 0,08$ \\
\hline
\end{tabular}

Data efisiensi pakan udang vaname selama pemeliharaan 35 hari terdapat pada Lampiran 6. Efisiensi pakan rata-rata (\%) udang vaname selama pemeliharaan 35 hari terdapat pada Tabel 5.2.

Hasil uji statistik menunjukan bahwa pemberian pakan dengan probiotik yang berbeda menghasilkan efisiensi pakan yang sangat berbeda nyata $(\mathrm{p}<0,05)$ terhadap udang vaname. Setelah dilanjutkan dengan uji Jarak Berganda Duncan (Duncan's Multiple Range Test) dapat diketahui bahwa efisiensi pakan tertinggi didapat pada perlakuan P9 yang berbeda nyata dengan perlakuan P0 serta perlakuan 
lainnya, sedangkan efisiensi pakan terendah didapat pada perlakuan P7.

Tabel 5.2. Efisiensi pakan rata-rata (\%) udang vaname pada setiap perlakuan selama penelitian 30 hari.

\begin{tabular}{cc}
\hline Perlakuan & Efisiensi Pakan \pm SD \\
\hline P0 & $43,99^{\mathrm{cd}} \pm 1,26$ \\
P1 & $48,23^{\mathrm{ab}} \pm 0,33$ \\
P2 & $46,34^{\mathrm{abc}} \pm 2,03$ \\
P3 & $46,81^{\mathrm{abc}} \pm 1,97$ \\
P4 & $43,91^{\mathrm{cd}} \pm 1,68$ \\
P5 & $48,2^{\mathrm{ab}} \pm 1,37$ \\
P6 & $42,09^{\mathrm{d}} \pm 2,05$ \\
P7 & $39,29^{\mathrm{e}} \pm 1,13$ \\
P8 & $45,54^{\mathrm{bc}} \pm 1,34$ \\
P9 & $48,80^{\mathrm{a}} \pm 1,23$ \\
\hline
\end{tabular}

\section{Pembahasan}

Hasil analisis statistik diatas menunjukkan bahwa pemberian pakan pada masing-masing perlakuan dengan probiotik yang berbeda menunjukkan perbedaan signifikan terhadap laju pertumbuhan harian udang vaname. Tabel 5.1 menunjukkan bahwa laju pertumbuhan tertinggi didapat pada perlakuan P9 dengan rata-rata pertumbuhan harian sebanyak 1,46 gram/hari. Peningkatan berat tubuh udang vaname selama penelitian menunjukkan adanya pertumbuhan. Effendie (1997) menyatakan bahwa pertumbuhan adalah pertambahan ukuran, berat atau panjang dalam suatu waktu. Pertumbuhan udang vaname disebabkan oleh beberapa faktor terutama adanya pasokan energi dari pakan. Kelebihan dari energi yang dibutuhkan untuk pemeliharaan dan aktifitas tubuh dimanfaatkan untuk pertumbuhan.

Pertumbuhan udang vaname tertinggi dengan perlakuan penambahan probiotik $\mathrm{C}$ yang ditambahkan ke pakan sebanyak $15 \mathrm{ml} / \mathrm{kg}$ menunjukkan peran aktif bakteri pada saluran pencernaan. Bakteri yang terkandung dalam probiotik $\mathrm{C}$ yaitu Lactobacillus sp., Nitrobacter sp., Geobacillus sp. dan Nitrosomonas sp. yang beraktivitas ketika masuk dalam saluran pencernaan yaitu tumbuh kemudian berko- loni. Bakteri Lactobacillus akan mengubah karbohidrat menjadi asam laktat, kemudian asam laktat dapat menciptakan suasana $\mathrm{pH}$ yang asam. Dalam keadaan asam, Lactobacillus memiliki kemampuan untuk menghambat bakteri pathogen dan bakteri pembusuk yang ada (Delgado et al., $2001 \mathrm{da}$ lam Rostini, 2007). Suasana asam pada usus akan meningkatkan sekresi dari enzim proteolitik (kecernaan pakan) dalam saluran pencernaan merombak protein menjadi asam amino yang kemudian diserap oleh usus. Pernyataan tersebut sesuai dengan pernyataan dari Gatesoupe (1999) dalam Mulyadi (2011) bahwa aktivitas bakteri dalam pencernaan organisme budidaya akan berubah dengan cepat apabila ada suatu mikroba yang masuk melalui pakan atau air yang dapat menyebabkan terjadinya perubahan keseimbangan bakteri yang sudah ada dengan bakteri yang masuk dalam saluran pencernaan tersebut. Adanya keseimbangan antara bakteri saluran pencernaan udang menyebabkan bakteri probiotik dapat bersifat antagonis terhadap bakteri patogen sehingga saluran pencernaan udang lebih baik dalam mencerna dan menyerap nutrisi pakan.

Efisiensi pakan adalah bobot basah dari daging ikan yang diperoleh per satuan berat kering pakan yang diberikan (Adelina dkk, 2012). Semakin tinggi nilai efisiensi pakan maka respon organisme budidaya terhadap pakan tersebut semakin baik yang ditunjukkan dengan pertumbuhan ikan yang cepat (Hariyadi dkk., 2005).

Hasil analisis statistik menunjukkan pemberian pakan pada masing-masing perlakuan dengan penambahan probiotik yang berbeda menunjukkan bahwa probiotik dalam pakan memiliki efisiensi pakan yang cukup baik bagi udang vaname. Hasil ratarata efisiensi pakan tertinggi yaitu terdapat pada perlakuan P9 $(48,80 \%)$, hal tersebut menunjukkan bahwa pada perlakuan P9 sesuai dengan kebutuhan nilai sehingga pencernaan dan penyerapan pakan yang dicampur probiotik efektif diserap untuk meningkatkan berat organisme udang 
budidaya dan persentasi pakan yang diubah menjadi daging meningkat.

Perlakuan P0 (kontrol) menunjukkan efisiensi pakan yang rendah termasuk juga pada perlakuan P4, P6 dan P7. Hal ini disebabkan oleh kurangnya penyerapan pakan serta rendahnya efisiensi pakan karena dipengaruhi aktivitas pencernaan yang tidak dibantu oleh adanya bakteri probiotik sehingga penyerapan energi untuk pertumbuhan udang juga kurang sempurna. Selain itu, efisiensi pakan juga di pengaruhi oleh dosis probiotik yang diberikan pada pakan sehingga dapat mempengaruhi keseimbangan mikroba yang ada di dalam saluran pencernaan udang.

Penggunaan pakan oleh udang menunjukkan nilai presentase pakan yang dapat dimanfaatkan oleh tubuh udang. Besar kecilnya nilai efisiensi pakan tersebut tidak hanya ditentukan oleh jumlah pakan yang diberikan, melainkan juga dipengaruhi oleh beberapa faktor seperti berat setiap individu, kepadatan, umur kelompok hewan, suhu air dan cara pemberian pakan (kualitas, penempatan dan frekuensi pemberian pakan). Semakin tinggi nilai efisiensi pakan maka respon udang terhadap pakan tersebut semakin baik yang ditujukkan dengan pertumbuhan organisme udang budidaya yang cepat (Hariyadi dkk., 2005).

\section{KESIMPULAN DAN SARAN Kesimpulan}

Dari hasil penelitian dapat diambil kesimpulan sebagai berikut: Pemberian probiotik komersial pada pakan berpengaruh terhadap laju pertumbuhan dan efisiensi pakan udang vaname (Litopenaeus vannammei) pada perlakuan P9.

\section{Saran}

Berdasarkan hasil penelitian yang telah dilakukan, pemberian probiotik $\mathrm{C}$ pada pakan dapat menghasilkan laju pertumbuhan dan efisiensi pakan dengan baik, sehingga dapat digunakan pada pakan dengan harapan dapat mengurangi biaya pakan dalam budidaya udang vaname. Pemberian probiotik sebaiknya disesuaikan dengan kadar mikroba yang sesuai untuk kondisi usus udang.

\section{DAFTAR PUSTAKA}

Adelina, Idasary Boer dan Fajar Amandiri Sejati. 2012. Penambahan Asam Lemak Linoleat (n-6) dan Linolenat (n-3) Pada Pakan Untuk Meningkatkan Pertumbuhan dan Efisiensi Pakan Benih Ikan Selais (Ompok hypopthalmus). Himpunan Alumni Fakultas Perikanan dan Ilmu Kelautan. Universitas Riau. Riau. Hal 66-79.

Effendi I. 1997. Biologi Perikanan. Yayasan Pustaka Nustama. Jakarta. 159 hal.

Fitriani, N. 2013. Pengaruh Pemberian Probiotik Berbeda Pada Pakan Komersial Terhadap Pertumbuhan dan Efisiensi Pakan Ikan Lele Sangkuriang (Clarias Sp.). Fakultas Perikanan dan Kelautan. Universitas Airlangga. Surabaya. 5 hal.

Fuller, R. 1987. A Review, Probiotics in Man and Animals. J Appl Bacteriol, 66:355-37.

Hadadi. A. 2007. Pemanfaatan Limbah Kelapa Sawit untuk Bahan Pakan. No. 1 Mei 2007 (11-18).

Haliman, R. W. dan Dian Adijaya S. 2006. Udang Vannamei. Penebar Swadaya. Depok. 76 halaman.

Handajani, H dan W. Widodo. 2010. Nutrisi Ikan. UMM Press. Malang.

Hariyadi, B., Haryono, A. dan Untung Susilo. 2005. Evaluasi Efesiensi Pakan dan Efisiensi Protein Pada Ikan Karper Rumput (Ctenopharyngodon idella Val) yang Diberi Pakan dengan Kadar Karbohidrat dan Energi yang Berbeda. Fakultas Biologi Unseod. Purwokerto.

Kementrian Kelautan dan Perikanan. 2013. Laporan Tahunan Direktorat Produksi Tahun 2013. Jakarta. hal 5. 
Kusriningrum. 2008. Perancangan Percobaan. Fakultas Perikanan dan Kelautan. Universitas Airlangga. Surabaya.

Mansyur, Abdul dan Abdul Malik Tangko. 2008. Probiotik: Pemanfaatannya untuk Pakan Berkualitas Rendah. Media Akuakultur Volume 3 Nomor 2 Tahun 2008. Balai Riset Perikanan Budidaya Air payau, Maros.

Mulyadi, A. E. 2011. Pengaruh Pemberian Probiotik Pada Pakan Komersil Terhadap Laju Pertumbuhan Benih Ikan Patin Siam. Skripsi. Fakultas Perikanan dan Ilmu Kelautan. Universitas Padjajaran. Bandung.

Rodryguez, A. Cuesta, A. Esteban, M. A. \& Meseguer, J. 2003. The Effect of Dietary Administration of The Fungus Mucor circnneloides on Nonspecific Immune Responses of Gilthead Seabream, Fish \& Shellfish Immunology. (16):241 249.

Rostini, I. 2007. Peranan Bakteri Asam Laktat (Lactibacillus plantarum) Terhadap Masa Simpan Filet Nila Merah pada Suhu Rendah. Fakultas Perikanan dan Ilmu Kelautan Jatinagor. Universitas Padjadjaran. 13 hal.

Soccol, C. R., Luciana Porto de Souza Vandenberghe, Michele Rigon Spier, Adriane Bianchi Pedroni Medeiros, Caroline Tiemi Yamaguishi, Juliano De Dea Lindner, Ashok Pandey dan Vanete Thomaz-Soccol. 2010. The Potential of Probiotics: A Review. Bioprocess Engineering and Biotechnology Department. Federal University of Paraná (UFPR). Brazil. P 413-434.

Sukenda., P. Hadi dan E. Harris. 2006. Pengaruh Pemberian Sukrosa sebagai Sumber Karbon dan Probiotik Terhadap Dinamika Populasi Bakteri dan Kualitas Air Media Budidaya Udang Vannamei, Lito- penaeus vannamei. Jurnal Akuakultur Indonesia, 5 (2) : 179-190.

Sumeru, S.U., dan S. Anna, 1992. Pakan Udang Windu Penaeus monodon. Kanisius. Jakarta.

Widanarni, Puguh Widagdo dan Dinamella. 2012. Aplikasi Probiotik, Prebiotik, dan Sinbiotik Melalui Pakan Pada Udang Vaname (Litopenaeus vannamei) yang Diinfeksi Bakteri Vibrio harvey. Fakultas Perikanan dan Ilmu Kelautan. Institut Pertanian Bogor. Bogor. Hal 32-49.

Widagdo, P. 2011. Aplikasi Probiotik, Prebiotik, dan Sinbiotik Melalui Pakan Pada Udang Vaname Litopenaeus Vannamei yang Diinfeksi Bakteri Vibrio Harveyi. Fakultas Perikanan dan Ilmu Kelautan. Institut Pertanian Bogor. Bogor.

Zonneveld, N., E.A. Huisman, and J.H. Boon. 1991. Prinsip-prinsip Budidaya Ikan. Penerbit PT Gramedia Pustaka Utama, Jakarta. 318 hlm. 